\title{
"Só quem sabe onde é Luanda saberá lhe dar valor": a tradição oral como herança ancestral
}

\author{
"Solely who knows where Luanda is will know how to value": oral tradition as \\ ancestral heritage
}

Julvan Moreira de Oliveira*, Kelly de Lima Farias**

Resumo: O objetivo desse trabalho foi refletir sobre a importância da tradição oral, tal como as possibilidades de esta se fazer presente nas práticas educativas brasileiras, provocado pelas experiências do estágio realizado na Escola Primária 16 de Junho, em Luanda, Angola, através do Programa de Intercâmbio Estudantil. Baseando-se em pesquisas bibliográficas de autores que dedicaram seus estudos à temática da tradição oral africana e seus desdobramentos, buscamos perceber a tradição africana não apenas como rica em aspectos históricos, mas como instrumento de conhecimento cultural que permeiam uma sociedade. Os aportes teóricos trazidos pretendem ampliar nosso olhar sobre o legado de culturas predominantemente orais que não se esvaziam de ensinamentos. Tais considerações nos ajudam a perceber que as várias práticas culturais negras desenvolvidas em nosso país abarcam as práticas e saberes africanos. Tido como um continente da palavra falada, a África reconhece a palavra como instrumento de preservação dos saberes ancestrais. A palavra é sagrada e composta de força vital. $\mathrm{Na}$ educação, a palavra, a oralidade, se faz presente, tal como na tradição oral. A oralidade, elemento da tradição, é mediadora das relações sociais, políticas, econômicas e culturais. Assim, concluímos pensando uma educação que através dos ensinamentos da tradição oral africana contribua para um conhecimento no qual o ser se envolve na totalidade.

Palavras-chave: Tradição Oral; Saberes Ancestrais; Práticas Educativas

Abstract: The objective of this paper was to reflect on the importance of the oral tradition, as well as the possibilities of this being present in the Brazilian educational practices, provoked by the experiences of the stage realized in Escola Primária 16 de Junho, in Luanda, Angola, through the Program of Student Exchange. Based on bibliographical researches of authors who have dedicated their studies to the theme of the African oral tradition and its unfolding, we seek to perceive the African tradition not only as rich in historical aspects but as an instrument of cultural knowledge that permeates a society. The theoretical contributions brought forward aim to broaden our view of the legacy of predominantly oral cultures that are not emptied of teachings. Such considerations help us to realize that the various black cultural practices developed in our country embrace

\footnotetext{
* Professor do Programa de Pós-graduação em Educação da Universidade Federal de Juiz de Fora (UFJF); membro do GT de Filosofia Africana e Afrodiaspórica da ABPN; Doutor em Educação pela USP; Licenciado em Filosofia pela USF. E-mail: julvan.moreira@ufjf.edu.br.

** Professora de Educação Infantil na Rede Municipal de Educação de Juiz de Fora; Graduada (2017) em Pedagogia pela UFJF. E-mail: kelly.moreno@hotmail.com
} 
African practices and knowledge. Considered as a continent of the spoken word, Africa recognizes the word as an instrument for the preservation of ancestral knowledge. The word is sacred and composed of vital force. In education, the word, orality, is present, as in the oral tradition. Orality, an element of tradition, mediates social, political, economic and cultural relations. Thus, we conclude by thinking of an education that through the teachings of the African oral tradition contributes to a knowledge in which the being is involved in the totality.

Key-words: Oral Tradition; Ancestral Knowledge; Educational Practices

\section{Introdução}

O objetivo desse trabalho é refletir sobre a oratura ou oralitura africana, provocado pelas experiências do estágio realizado na Escola Primária 16 de Junhor ${ }^{1}$, em Luanda, Angola, através do Programa de Intercâmbio Internacional de Graduação da Universidade Federal de Juiz de Fora (UFJF) em cooperação com a Universidade Agostinho Neto (UAN), realizado entre março de 2014 a fevereiro de 2015, cujos os objetivos deste intercâmbio foram: realizar o levantamento de livros infantis e infanto-juvenis adotados nas escolas da capital angolana; analisar a construção da identidade étnica presente nestas obras e observar a contribuição que essas obras possam ter na construção da identidade étnica da criança negra brasileira.

Esse intercâmbio permitiu que fossem refletidos alguns momentos em que se notou como a tradição é vivida e sentida, como os costumes são transmitidos através do modo de se viver, através das vozes, das cores existentes em cada vestimenta, em cada palavra que se faz viva. Assim, aquele que sabe como aquele que não sabe onde é Luanda, poderá se encantar, e refletir acerca do repertório cultural que envolve suas gentes.

Ao que nos parece, quase todos em Luanda tem um "que" de ator, de contador de histórias. Parece ser algo inerente daquele povo que em suas vozes trazem novas nuances a uma fala já dita. E aquele que a ouve, pelo prazer e encantamento, fica atento apreciando tal habilidade. A sensação é que essa gente se diverte com as palavras.

O andar, o olhar, o bailar, o cantar, o sorrir e o falar, quanta grandeza se reúne em um ser. Somos microcosmos, reluzentes, plenos de histórias que nos compõem. A fala, a voz, as cordas vocais são fios que tecem (dis)cursos que conduzem a uma infinita herança ancestral; o ritmo vocal embala as manifestações, os processos de transformações e tradições de um povo. A voz que ressoa, conecta o passado ao presente trazendo aos ouvidos a vivência que carece ser perpetuada.

\footnotetext{
${ }^{1} 16$ de Junho, nome da escola, é o dia da criança africana, homenagem às centenas de crianças assassinadas e milhares feridas no dia 16 de Junho de 1976 em Johannesburg, Soweto, África do Sul.
} 
Dessa forma, iniciamos com breves considerações de intelectuais sobre a tradição oral, um convite para uma reflexão sobre sua importância em África. Esta tradição pode consistir desde um ensinamento moral a uma norma de vida, os ecos ancestrais tecem histórias de rico aprendizado.

Em seguida, apontamos as possíveis designações para tradição oral, destacando a relevância da palavra e os conjuntos de saberes trazidos por ela que muitas vezes foram colocados à margem em função de estereótipos, seja pela ausência de registros concretos seja pela problemática conceitual da tradição oral.

Dando sequência, adentraremos a questão de a oralidade conceder a mesma confiança que se concede à escrita quando se trata de testemunho de fatos já ocorridos. Procurando assim, identificar as leituras que compreendem as características da memória para a tradição africana.

Nós gostaríamos de reafirmar que nos interessa não somente mencionar as proximidades culturais entre Brasil e o continente africano, mas chamar a atenção como essas práticas culturais que preservam saberes ancestrais, podem ser possibilidades fecundas na educação brasileira.

Acerca da cultura tradicional africana que se pauta essencialmente na transmissão oral dos seus saberes, um dos importantes legado que nos permite mergulhar nesse universo, nos foi deixado por Amadou Hampâté Bâ. O filósofo malinês ao dizer que "na África cada ancião que morre é uma biblioteca que se queima" ${ }^{2}$ acaba por nos revelar a importância da voz, da transmissão oral no continente africano e a grandeza de ouvir um sábio africano relatar suas experiências; é como se vários livros se abrissem, com uma profusão de detalhes, para dar voz às histórias e às tradições locais.

As escolas Primárias em Angola são as escolas que lecionam desde a $1^{\mathfrak{a}}$ a $6^{\underline{a}}$ classe. O ensino primário em Angola é tido como fundamento para o ensino geral, têm acesso ao ensino primário as crianças com 6 anos de idade, cuja função social é desenvolver capacidades e aptidões no aluno, defendendo um currículo que agrupa diversas facetas da cultura, do desenvolvimento social e pessoal. E, uma das primeiras lembranças sobre essa escola é a seguinte:

Para frequentar a escola, era necessário usar a bata branca, que em Angola foi adotada com o objetivo de avaliar o asseio, prevenir a desigualdade social entre os alunos na sala e evitar o assédio por parte das meninas. Por entre olhares curiosos, e cabeças adornadas com puchinhos ${ }^{3}$, as crianças da escola, perguntavam acerca do meu uniforme, que para elas era sinal de respeito e colocava todos em pé de igualdade. Sobre respeito, outro hábito na escola, era o levantar dos alunos ao adentrar na sala de aula uma pessoa importante, por exemplo, um professor, um diretor, um supervisor ou um

\footnotetext{
${ }^{2}$ BÃ, Confrontações Culturais, p. 08-09.

${ }^{3}$ Penteado feito com ligas de elástico e tranças.
} 
visitante. Todas as crianças ficam de pé, e em coro dizem: "Boa tarde senhora professora ou senhor visitante" e só após o recebimento dos cumprimentos pelo visitante é que elas se sentam novamente em seus lugares. Questões que inicialmente causam certo desconforto para quem não vive esta realidade, e que a mim não era diferente, entretanto, este "estar de pé", foi sendo substituído por um caloroso abraço coletivo à minha chegada, estabelecendo assim uma relação de afetividade em sala de aula.

E nesse clima de afeto é que os olhares tímidos foram se transformando em sorrisos criando um ambiente propício para as perguntas que surgiam a cada novo encontro naquela escola.

- Professora, falas brasileiro?

- Professora, teu cabelo é “postiço"”?

- Professora, como são as crianças brasileiras?

- Professora, sabes jogar "zero"

Perguntas estas muito frequente nos primeiros dias de contato com os alunos da Escola Primária 16 de Junho. Estabelecer esta relação de vínculo é um processo importantíssimo, pois pouco a pouco se tece a trama dos costumes daquele lugar, assim a oralidade vai assegurando seu lugar de importância não apenas na fala dos "mais velhos", mas na doce palavra da criança, que trama e borda lindas narrativas nos ajudando a compreender o papel de transmissão dos saberes que povoam a sociedade africana.

(Notas do caderno de campo).

Figura 1: Crianças da Escola Primária 16 de Junho, em Luanda, Angola com estagiária Kelly.

\footnotetext{
${ }^{4}$ Cabelo artificial.

${ }^{5}$ Brincadeira feminina em que as jogadoras, frente a frente, lançam os pés, como em um sapateado, seguindo um ritmo ditado por palmas; os pés devem formar par (pé esquerdo de uma com o pé direito da outra), quem tiver escolhido "o par" ganha um ponto. Assemelha-se ao "par ou ímpar".
} 


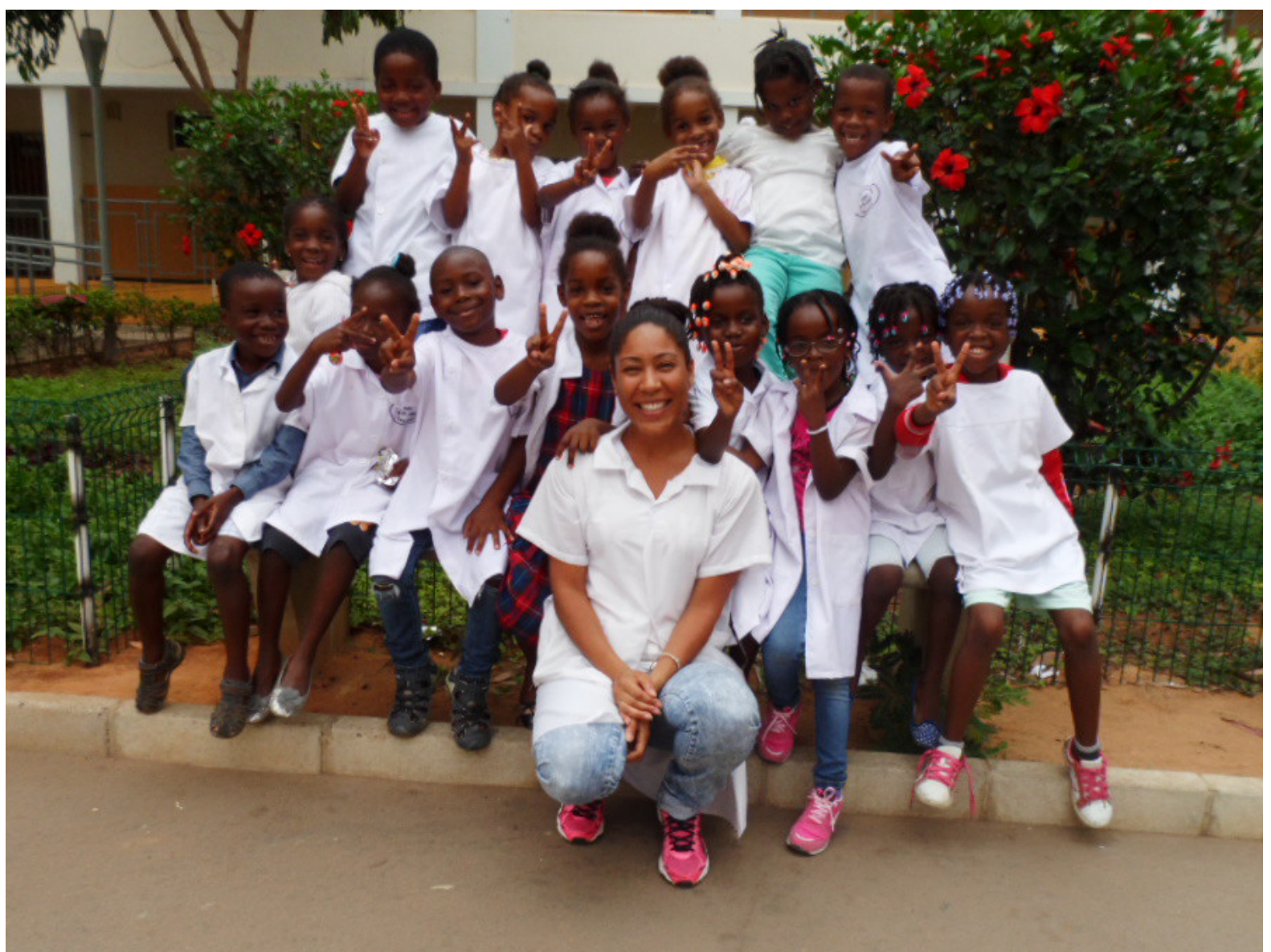

Fonte: arquivo pessoal de Kelly de Lima Farias.

A tradição oral provoca um encanto sobre aqueles que se aventuram nessa senda, pois esta revela um mundo a ser descoberto através da fala. Para quem está na diáspora e faz o primeiro contato com esta maneira peculiar de tecer o cotidiano, compreende que se coloca diante de múltiplas possibilidades de rico aprendizado. E dessa forma se encanta e escolhe conhecer curso a tradição oral africana, como forma de construção da própria identidade.

Há um mundo de histórias na fala, em Angola, por exemplo, um país de raiz de tradição oral, há uma multiplicidade de sentidos, uma miscelânea de vocábulos, onde a marca da oralidade está presente no cotidiano das pessoas de forma tão fluida que até mesmo uma explicação acerca de um possível atraso ao trabalho pode virar uma história. A marca do oral está nas histórias contadas pelos "mais velhos”, representados aqui não com sentido pejorativo, onde o "mais velho" não diz respeito à idade, mas ao acúmulo de conhecimento. Nessa fala, fatos, lendas e costumes são transmitidos e fortalecidos como herança cultural.

Em um tempo em que o papel necessita ser preenchido pela tinta para que exista história, contudo, é a oralidade destituída de valor que nos provoca interesse de estudo, no sentido que nos aponta Silva ${ }^{6}$.

${ }^{6}$ SILVA, Os "Fios de Contos" de Mãe Beata de Yemonjá: mitolofia afro-brasileira e educação, 2008. 
Muito embora as civilizações africanas em grande parte fossem civilizações da palavra falada, é preciso levar em conta a existência da escrita antes da chegada dos colonizadores europeus ao continente africano, entretanto a predominância era de civilizações orais.

A tradição oral africana poderá ser uma grande aliada na educação para o resgate da identidade afro-brasileira, pois "a dimensão da oralidade abrange todas as culturas tradicionais afro-brasileiras”, como aponta Oliveira ${ }^{7}$. A voz não silenciada é uma voz que vibra e faz vibrar em nós o encanto perene das tradições do povo africano. Nesse universo destacam-se elementos significativos como, música, religião ensinamentos, ritos, mitos, cantos, dança, poesias que podem ser trabalhados nas práticas educativas.

A tradição oral africana pode ser vista como elo com a nossa ancestralidade, já que elementos dessa tradição foram trazidos para o Brasil principalmente através dos africanos escravizados e foram sendo incorporados através das culturas negras aqui existentes ao universo da cultura nacional. Portanto, conhecer a história dos nossos ancestrais se faz necessário para que possamos compreender os desdobramentos dessa presença, como nos torna também responsáveis em transmiti-la.

Embalada pelo calor angolano e pelo ritmo das vozes que cresciam em espiral, um breve pensamento toma corpo neste poema autoral:

Pérola Negra

Vivias em meus sonhos

Desejei em tuas terras pisar

És bela em todo e qualquer detalhe

Tua pluralidade é singular

A zungueira com a cria nas costas e olhar distante

traz ainda o suor que a noite não secou

Os amantes se despedem em longos olhares

enquanto a madrugada se deita nos lençóis do sol

Começa a labuta, o guerreiro da urbe já está na via

O amarelo de seus olhos entrega as lutas travadas

Até seu silêncio grita

\footnotetext{
7 OLIVEIRA, Africanidades e Educação: ancestralidade, identidade e oralidade no pensamento de Kabengele Munanga, p. 224.
} 
Tua gente sai sob o sussurro do vento para zungar entre os guetos

Dores e cores se misturam ao suor no rosto

Que caindo na terra faz germinar a esperança

Nessa terra que dança, nos sorrisos que bailam

Aiwe minha Angola! ${ }^{8}$

O continente africano tido como o berço da humanidade carrega de forma tão singular a marca da voz, a voz de um povo rico em sabedoria, a voz de povo que fora muitas vezes silenciada pela colonização, mas não calada. África ${ }^{9}$ guarda embaixo de cada árvore, ao redor de cada fogueira acesa, os ecos ancestrais das vozes que tecem a memória de muitos saberes, transcendendo tempo e espaço trazendo vida e longanimidade às tradições locais.

A voz era o meio que homens e mulheres utilizam para reproduzir suas memórias, que ao transmiti-las de geração em geração era possível perpetuá-las. Vansina ${ }^{10}$ retrata pontualmente a questão oral:

Uma sociedade oral reconhece a fala não apenas como um meio de comunicação diária, mas também como um meio de preservação de sabedoria dos ancestrais, venerada no que poderíamos chamar elocuçõeschave, isto é a tradição oral. A tradição, pode ser definida, de fato, como um testemunho transmitido verbalmente de uma geração para a outra.

Para Vansina, as tradições são fontes para o conhecimento do passado, são as fontes mais importantes para o estudo da história dos povos ágrafos.

Escrever sobre a tradição oral africana não é tarefa simplista, engana-se quem pensa ser fácil aventurar-se nessas águas. Ao ler um texto oral temos que nos deixar encantar, pois não há como lê-lo uma ou duas vezes e acreditar que já o compreendemos como um todo, devemos cuidadosamente examiná-lo para que possamos apreender seus muitos significados. Em uma sociedade como a que vivemos, na qual dispomos de meios tecnológicos, das tecnologias de informação, debruçar-se sobre a literatura oral implica em "aprender a trabalhar mais lentamente, refletir, para embrenhar-se numa representação coletiva, já que o corpus da tradição é a memória coletiva de uma sociedade” ${ }^{11}$.

\footnotetext{
${ }^{8}$ FARIAS, Poema autoral.

${ }^{9}$ É oportuno destacar que não podemos nos limitar em dizer que existe uma só África. A pluralidade de civilizações, povos, culturas, línguas e religiões faz do território africano um mosaico com múltiplas identidades.

${ }^{10}$ VANSINA, A tradição oral e sua metodologia, p. 157.

${ }^{11}$ Ibidem, p. 158.
} 
A tradição oral abrange o entendimento e conhecimento humano, liga o homem ao seu espaço, seu papel e seu universo, nos aponta Vansina, ao estudar sociedades orais africanas.

As narrativas orais nas sociedades tradicionais africanas podem ser tidas como os pilares em que se apoiam os valores e as crenças transmitidas pela tradição. Uma tradição de acordo com esse autor, é uma mensagem transmitida de uma geração para a seguinte. No entanto, para ele, nem toda informação verbal é uma tradição, podendo ser somente o relato de um testemunho ocular, mas quando essa informação é repetida por gerações posteriores torna-se então tradição. Assim, são tradições orais as fontes narradas, as que são transmitidas de boca em boca através da linguagem.

\section{Eu digo, tu me escutas - tradição oral, literatura e os desafios de uma designação perfeita}

Se formulássemos a seguinte pergunta a um verdadeiro tradicionalista africano: ' $O$ que é tradição oral?', por certo ele se sentiria muito embaraçado. Talvez respondesse simplesmente, após longo silêncio: "É o conhecimento total" 12.

Ao falar de tradição em relação à história africana, Hampâté Bâ ${ }^{13}$ reitera que "nenhuma tentativa de penetrar a história e o espírito dos africanos terá validade a menos que se apoie nessa herança de conhecimentos de toda espécie, pacientemente transmitidos de boca a ouvido, de mestre a discípulo”.

É desafiador falar sobre tradição oral africana, este desafio se dá pela dificuldade de encontrar uma designação que possa abarcar todos seus aspectos. A tradição oral possui características peculiares, a saber, o verbalismo e a maneira como é transmitida, diferindose das fontes escritas. A cultura da oralidade para a transmissão de conhecimentos e perpetuação das tradições é uma marca do continente africano, que, durante muitos séculos se manteve sem a interferência da escrita vivendo na memória dos mais velhos.

Assim, essa memória viva ao recuperar as narrativas dos mais velhos, cumpre o papel de transmitir saberes africanos, ajudando a tecer os fios da continuidade.

É preciso retomarmos que África ao longo de muitos séculos foi alvo de diversos interesses, sobretudo interesses relacionados à exploração de seu território. Com a colonização nos países africanos, uma importante mudança pode ser observada nas sociedades tradicionais, que passaram a incorporar outras línguas e outros costumes. Não obstante, o processo colonialista em África para além da exploração territorial procura modificar o olhar do africano para si mesmo, para a sua cultura, estabelecendo então

\footnotetext{
${ }^{12}$ BÂ, A tradição viva, p. 182.

${ }^{13}$ Ibidem, p. 181.
} 
condições de estranhamento e descontentamento de sua própria cultura, em favor da cultura europeia.

Os territórios onde o colonizador hasteou sua bandeira são locais onde mergulhamos em um mar de narrativas e valores que o colono não conseguiu apagar. Em "Eu e o outro - o invasor”, Manuel Rui ${ }^{14}$ relata:

Quando chegaste mais velhos contavam estórias. Tudo estava no seu lugar. A água. O som. A luz. $\mathrm{Na}$ nossa harmonia. O texto oral. E só era texto não apenas pela fala mas porque havia árvores (...). E era texto porque havia gesto. Texto porque havia dança. Texto porque havia ritual. Texto falado ouvido visto. É certo que podias ter pedido para ouvir e ver as estórias que os mais velhos contavam quando chegaste! Mas não! Preferiste disparar os canhões.

O escrito de Manuel Rui descreve a ação do colonizador que, pela força de suas armas, e principalmente pela escrita veio ameaçar a identidade africana. A identidade de um povo, tal como, seus costumes, religiosidade, tradições, dizem respeito à constituição social da memória. Como vimos, o falar é desconsiderado e apenas o que é escrito torna-se válido, ou seja, a existência de uma história está embasada naquilo que é documentado.

Nessa esteira, pensamentos que relegam ao continente africano a ideia de inferioridade, têm raízes profundas como as raízes de um baobá, notando-se um preconceito arraigado de que os africanos não teriam tido qualquer participação na história da civilização.

A Europa exemplificava o estado adulto da civilização, enquanto as culturas nãoeuropeias eram encaradas como símbolos de um estado de infância, através do qual a Europa já tinha passado. Encarada sobre este prisma, a tradição oral era considerada primitiva ${ }^{15}$.

O europeu era considerado como o apogeu de um processo evolutivo, sendo esta a justificativa para exercer o domínio sobre outros povos. Foi com esse pensamento que se deu também "a exclusão do negro na construção da nacionalidade brasileira” ${ }^{16}$, justificadas por uma filosofia etnocêntrica desenvolvida no ocidente ${ }^{17}$.

\footnotetext{
${ }^{14}$ RUI, apud NUNES, A milenar arte da oratura angolana e moçambicana: aspectos estruturais e receptividade dos alunos portugueses ao conto africano, p. 41.

${ }^{15}$ LEITE apud NUNES, A milenar arte da oratura angolana e moçambicana: aspectos estruturais e receptividade dos alunos portugueses ao conto africano, p.41.

${ }^{16}$ OLIVEIRA, Africanidades e Educação: ancestralidade, identidade e oralidade no pensamento de Kabengele Munanga, p. 94-98.

${ }^{17}$ OLIVEIRA; NASCIMENTO, A construção do legado: a negação de uma epistemologia filosófica africana, p. 177-194.
} 
Entretanto contrariamente à ideia de povos pouco evoluídos e trazendo luz aos créditos conferido à tradição oral, Vansina ${ }^{18}$, explica que tudo que uma sociedade considera importante para o perfeito funcionamento de suas instituições é feito através da transmissão que, em uma sociedade oral é feita pela tradição; enquanto numa sociedade escrita somente as memórias de menos importância são dedicadas à tradição. Para ele, "é esse o fato que levou durante muito tempo os historiadores, que vinham de sociedades letradas, a acreditar erroneamente que as tradições eram um tipo de conto de fadas, canção de ninar ou brincadeira de criança" ${ }^{19}$. Fato que colabora com o pensamento de uma África inferiorizada.

Negada qualquer dimensão histórica aos seus povos, o continente africano passou a ser estudado como povos sem história por não disporem de documentos escritos, entretanto, a ausência de registros concretos não exime a existência de um passado ou que os seus conhecimentos e cultura sejam transmitidos e conhecidos. Enquanto a escrita constitui-se como elemento técnico, a palavra liga-se à ação do homem que revela as principais proposições históricas de uma dada sociedade.

Percebemos que os estereótipos negativos advindos de tempos remotos engendram a problemática conceitual da tradição oral. Entretanto, é valido e pertinente ressaltar o valor da memória e da tradição oral africana, pois os povos que passaram pela opressão do colonizador, estabeleceram mecanismos de resistência às condições a que foram submetidos, passaram ainda a afirmar o valor da tradição africana e sua transmissão, garantindo assim a preservação dos traços culturais e civilizatórios mesmo em um contexto de colonização.

Vansina propõe em seus estudos uma reflexão importante às tradições, incluindo a elas não somente os depoimentos orais que descrevem acontecimentos passados, mas também toda uma literatura oral que fornecerá detalhes sobre o passado, sendo fonte importante para a história das ideias, dos valores e da habilidade oral. "As tradições são também obras literárias que deveriam ser estudadas como tal, assim como é necessário estudar o meio social que as cria e transmite e a visão de mundo que sustenta o conteúdo de qualquer expressão de uma determinada cultura” ${ }^{20}$.

Segundo Hampâté Bâ ${ }^{21}$, ao contrário do que alguns pensem, a tradição oral, não se restringe às lendas, ou mesmo a relatos mitológicos ou históricos, e os griots estão longe de ser seus únicos guardiães. A esse respeito ele diz:

A tradição oral é a grande escola da vida, e dela recupera e relaciona todos os aspectos. Pode parecer caótica àqueles que não lhe descortinam o

\footnotetext{
${ }^{18}$ VANSINA, A tradição oral e sua metodologia, 2010.

${ }^{19}$ Ibidem, p. 163.

${ }^{20}$ Ibidem, p. 159.

${ }^{21} \mathrm{~B} \hat{\mathrm{A}}$, A tradição viva, 2010.
} 
segredo e desconcertar a mentalidade cartesiana acostumada a separar tudo em categorias bem definidas. (...) Ela é ao mesmo tempo religião, conhecimento, ciência natural, iniciação à arte, história, divertimento, recreação, uma vez que todo pormenor sempre nos permite remontar à Unidade primordial ${ }^{22}$.

Para o malinês Hampâté Bâ, a fala é o grande agente ativo da magia africana, esta magia não é nada mais que o controle das forças. Segundo ele, na Europa a palavra magia geralmente é tomada pelo seu mau sentido, mas em África é algo neutro que pode ser benéfica ou maléfica de acordo com o direcionamento que lhe é dado.

É nesse contexto mágico-religioso e social que se encontra o respeito à fala, principalmente quando esta é responsável por transmitir as palavras dos ancestrais. Dessa forma, cabe considerar, que a palavra é sagrada onde o sopro vital habita, portanto não deve ser confundida com a oralidade humana informal, ou ser mau usada; mas deve ser concebida como elemento de continuidade histórica. Nas sociedades orais, o homem está ligado à palavra que profere, a palavra é testemunho daquilo que ele é.

O texto oral transmite um legado legítimo das culturas locais através de exemplos que solidificam os laços e garante o discernimento do lugar de pertença do indivíduo, sua filiação identitária, permitindo-lhe uma visão de si mesmo e do outro.

O que os estudiosos como Hampâté Bâ ${ }^{23}$ e J. Vansina ${ }^{24}$ designam como tradição oral nos remete a considerá-la como aquela transmitida através da oralidade, tradição que conduz o homem à sua totalidade. Susana Dolores Machado Nunes ${ }^{25}$, explica que a expressão "tradição oral" por encerrar um caráter generalizante, é geralmente evitada quando se pretende designar especificamente os textos literários de expressão oral. Dentro dessa perspectiva de apontar uma denominação apropriada, a autora adota em seu estudo o termo "oratura", reconhecendo a "presença da oralidade enquanto meio de transmissão de um corpus vivo" ${ }^{26}$, e a escrita como suporte que garante a conservação deste.

Embora haja uma diversidade de designações, pensar a tradição oral sob a ótica da transmissão através da oralidade é uma constatação viável, pois constitui-se não apenas como veículo de comunicação e reprodução social, mas como meio de desenvolvimento humano e de construção de uma imagem de mundo.

\section{Entre a palavra e o papel: a tradição}

\footnotetext{
${ }^{22}$ Ibidem, p. 183.

${ }^{23}$ Ibidem.

${ }^{24}$ VANSINA. Op. Cit.

${ }^{25}$ NUNES, A milenar arte da oratura angolana e moçambicana: aspectos estruturais e receptividade dos alunos portugueses ao conto africano, p. 33.

${ }^{26}$ Ibidem, p. 35.
} 
Segundo Nunes "as literaturas africanas modernas, na sua forma escrita, nascem intrinsecamente ligadas à experiência da colonização, uma vez que, como é sabido, a arte verbal tradicional se exprime através da oralidade" 27.

Ana Mafalda Leite ${ }^{28}$ reitera afirmando que o fenômeno da escrita dos textos orais decorre, em parte, do acesso à independência da maioria dos países africanos na década de sessenta e do desejo de conhecimento e revalorização do seu patrimônio oral.

É nesse contexto, que as obras dos intelectuais africanos ganham destaque, tais obras desconstroem a premissa que a literatura oral era encarada como uma manifestação primária, simples, não sujeita a trabalho reflexivo, um produto de uma comunidade, enquanto a literatura escrita revelava o oposto $^{29}$.

Face a essa premissa e aos preconceitos acerca da ausência da escrita em África, se faz pertinente destacar o trabalho realizado por intelectuais africanos, que procuraram salvaguardar a memória e as tradições do continente; estes partem de uma visão endógena e não de uma perspectiva constituída pela visão do colonizador. A representação da África através da ótica do africano reflete aquilo que lhes é mais próximo em suas culturas, a questão da identidade começa a ganhar corpo. Os escritores africanos encontram embasamento para seu projeto literário de reconstrução da identidade nacional na tradição oral, transformando, assim, sua narrativa num espaço de expressão da memória coletiva. Assim, a perpetuação da tradição encontra veículo poderoso nos textos literários.

É comum entre alguns estudiosos indagar sobre a oralidade pode conceder a mesma confiança que se concede à escrita quando se trata de testemunho de fatos já ocorridos. Nesse sentido possíveis questionamentos se levantam no que diz respeito a utilização da linguagem escrita para transmitir saberes ancestrais. Como traduzir a oralidade dos relatos dos "mais velhos" numa narrativa escrita?

Apesar do dilema de exprimir uma sensibilidade e uma mensagem singular existente na linguagem oral por meio do código linguístico, vários escritores têm se empenhado em realizar esta tarefa. Alguns se dedicaram a reescrever contos, lendas e fatos recolhidos junto aos habituais detentores da palavra da tradição nessas sociedades, outros escritores usaram a escrita em defesa de um sentimento de liberdade, nesse caso as obras literárias ganharam a força da expressão do anticolonialismo.

É interessante perceber que antes da escrita, o homem recorda os fatos tal como lhe foram narrados ou como foram vividos através de sua própria experiência. Assim no intercâmbio tradição/escrita, é possível constatar as marcas da oralidade presentes no

\footnotetext{
${ }^{27}$ Ibidem, p. 38.

${ }^{28}$ LEITE, Oralidades e Escritas nas Literaturas Africanas, 2014.

${ }^{29}$ Ibidem, p. 19.
} 
enredo das obras. A oralidade é nas sociedades tradicionais africanas, a fonte de transmissão dos conhecimentos, pois "nada prova a priori que a escrita resulta em um relato da realidade mais fidedigno do que o testemunho oral transmitido de geração a geração" ${ }^{30}$.

De acordo com Vansina ${ }^{31}$, a memória africana, de modo geral, surpreende pelo seu alcance e espanta pelo seu registro detalhista. A tradição oral tem na memória o aliado indispensável para sua continuidade.

Antônio Filogênio de Paula Junior ${ }^{32}$ nos suscita um questionamento quando indaga o fato de um memorialista estar fazendo uso das letras: "Como um homem da tradição oral, transfere os saberes para uma forma escrita?”

Embora haja dificuldades em conciliar estas formas de transmissão do saber é importante pontuar que, no caso africano, a memória insere-se no que se chama de tradição viva. Nessa perspectiva, Hampâté Bâ nos propõe uma reflexão considerável, ao dizer que para estes povos, ao relacionarem a palavra a um universo de sacralidade na qual todas as coisas se conectam, acabam por ter no universo da tradição oral um solo de segurança em relação à coerência e autenticidade dos relatos.

O que se encontra por detrás do testemunho, portanto, é o próprio valor do homem que faz o testemunho, o valor da cadeia de transmissão da qual ele faz parte, a fidedignidade das memórias individual e coletiva e o valor atribuído à verdade em uma determinada sociedade. Em suma: a ligação entre o homem e a palavra ${ }^{33}$.

A compreensão do diálogo entre oral e o papel tem sido um desafio para diversos pesquisadores das culturas orais. Nunes ${ }^{34}$ salienta que o memorialista ao utilizar a escrita, desenvolve uma oratura, ou melhor, uma representação escrita da tradição oral.

Cabe elucidar que não se pretende nesse trabalho responder a tais questionamentos, fazer juízo de valor entre a palavra e a escrita ou traçar a superioridade de uma delas, mas exprimir a ideia de continuidade entre as tradições orais e a literatura africana. Nunes ressalta que "a escrita constitui um suporte que garante a conservação da performance passada de uma criação coletiva anônima” ${ }^{35}$. Para ela, é uma escrita que tem cheiro, sabor e muitas cores. Através desta oralidade escrita temos podido nos aproximar de uma África muitas vezes estigmatizada pelas misérias, barbáries e exotismos. As argumentações de uma África vitimada devem, portanto, dar lugar a uma África que tem em seu conjunto civilizatório elementos socioculturais a serem refletidos e compartilhados.

\footnotetext{
${ }^{30}$ BÂ, A tradição viva, p. 182.

31 VANSINA, Op. Cit.

32 PAULA, Educação e Oralidade na Cultura Negra no Brasil, p. 93.

${ }^{33}$ BÃ, Op. Cit., p. 182.

${ }^{34}$ NUNES, Op. Cit.

${ }^{35}$ Ibidem, p. 35.
} 


\section{Tradição oral na escola: possibilidades}

A partir dos estudos acerca da tradição oral africana vimos que esta, se apoia na transmissão dos saberes através da oralidade. No entanto, essa oralidade não é tratada aqui como a fala informal e rotineira, mas vista pela ótica de sua potencialidade e habilidade.

A história e memória dos povos africanos está presente na cultura negra no Brasil. As proximidades culturais em Brasil e o continente africano não são recentes. Durante o período de colonização, as terras brasileiras receberam milhares de africanos na condição de escravizados. Tais indivíduos trouxeram também um aparato cultural que teve influência na estruturação da cultura dos negros no Brasil.

De acordo com Nunes ${ }^{36}$, os africanos que chegavam ao Brasil eram trazidos de diferentes regiões da África, pertenciam a várias etnias e a estágios culturais diversos. Havia indivíduos de Estados politicamente organizados, de sociedades que dominavam tecnologias sofisticadas, como por exemplo, o uso dos metais, negras e negros praticantes do islamismo que sabiam ler e escrever, o que contrasta com a ideia de que os africanos eram oriundos de tribos primitivas e exóticas.

Assim sendo, através da transmissão dos saberes, os africanos recriaram a memória dos feitos ancestrais, ressignificando a vida nos lugares que passariam a viver. Portanto, as características da oralidade estão enraizadas na cultura negra desenvolvida no Brasil.

Antônio Filogênio de Paula Junior ${ }^{37}$, aponta que o universo cultural africano e a tradição oral foram taticamente reinventados em nosso país como forma de garantir ao escravizado a sua condição humana em contraposição à condição determinada pelo colonizador. Portanto, o autor, ressalta ainda que de acordo com Cunha Junior, os modos de ser dos africanos, foram arranjados em solo brasileiro, de maneira que as principais características, ou aquilo que determinaria sua essência estivesse assegurado.

Nesse sentido, buscamos nessa trama, não somente apontar as proximidades culturais entre o Brasil e o continente africano e suas ressignificações, mas trazer à luz como essas práticas culturais revelam saberes ancestrais em terras brasileiras. Uma vez que a tradição do universo africano se faz presente na cultura negra no Brasil através dessas práticas, podemos pensar esta tradição fazendo-se presente também na escola.

Uma certa manhã africana brindou-me com seus tons laranja e uma grata conversa:

- Professora, você será nossa professora brasileira?

- Professora brasileira?

\footnotetext{
${ }^{36}$ NUNES, A cultura de base africana e sua relação com a educação escolar, 2011.

${ }^{37}$ PAULA, Op. Cit.
} 
- Sim? Como os teus alunos te chamam lá?

- Me chamam de tia!

- Tia?

- Lá nos chamam por vezes de tia sim!

- Tia? Assim és mais velha então - entre muitos risos dizia- uma tia aqui é uma kota ${ }^{38}$ !

Fobada ${ }^{39}$ para morder uma bela magoga ${ }^{40}$, de súbito ouço a criança disparar: - Epah estás a comer magoga, ewe não faz isso professora, mamã diz que magoga mata as pessoas e que é comida de feiticeiro! Come ginguba!

A criança jogou as gingubas em minhas mãos. Sorri, guardei a magoga e levei os ensinamentos comigo. Magoga, o tal pão com frango, que matara minha fome nos dias de estágio, era agora comida de feiticeiro, kota eu deduzi o que pudesse ser, ou seja, uma pessoa mais velha e ginguba eram os amendoins que eu havia ganhado para não comer a tal comida enfeitiçada ${ }^{41}$.

Figura 2: Criança na sala de aula da Escola Primária 16 de Junho, Luanda, Angola.

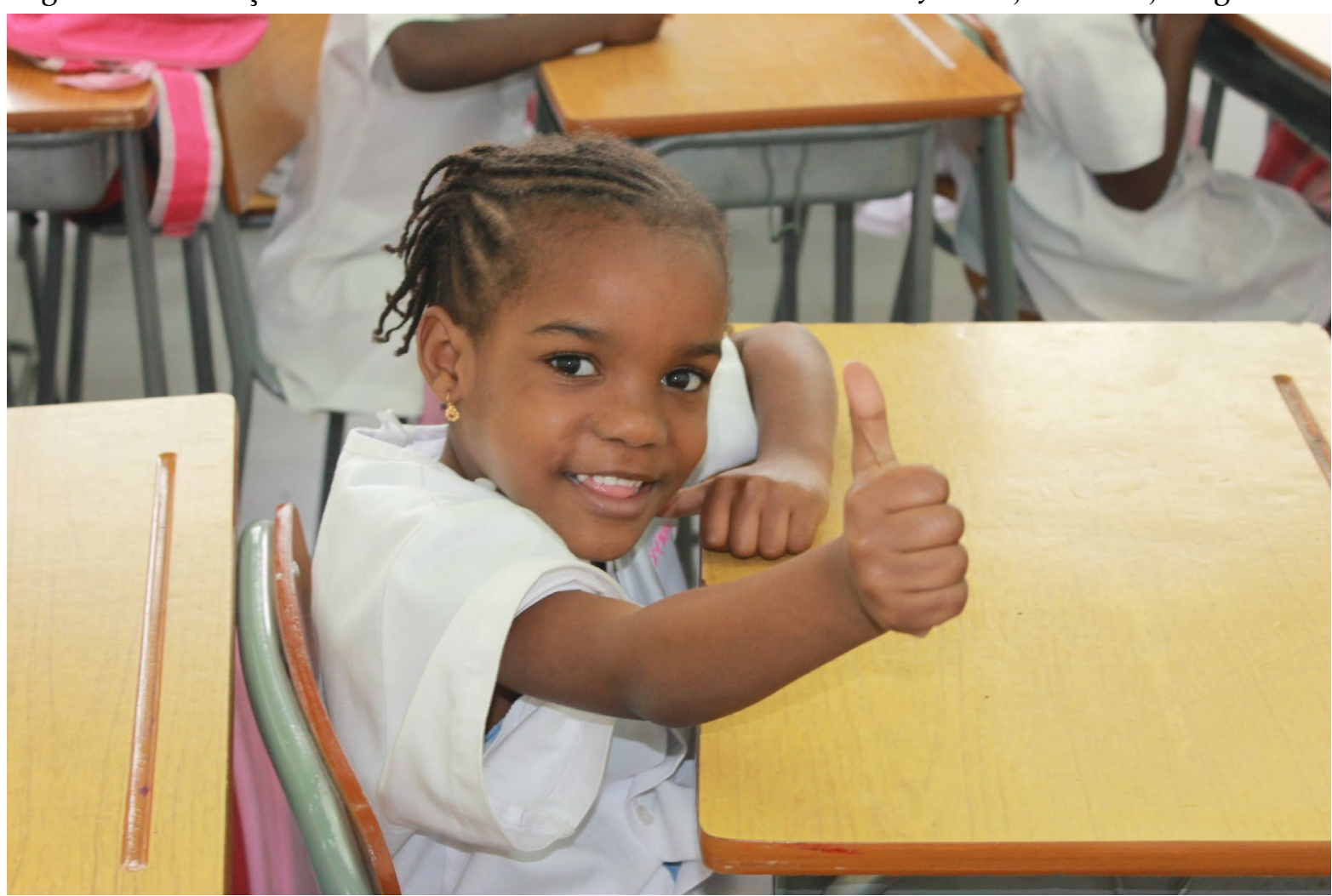

Fonte: arquivo pessoal de Kelly de Lima Farias.

\footnotetext{
${ }^{38}$ Pessoa mais velha.

${ }^{39}$ Com fome.

${ }^{40}$ Pão com frango recheado de molho, repolho e batata frita.

${ }^{41}$ Notas do caderno de campo.
} 
Para Cícera Nunes ${ }^{42}$ a escola enquanto uma instituição que tem o papel de organizar, socializar e transmitir o conhecimento sobre a história, a cultura e a sociedade, pode se transformar em um importante local de diálogo, troca de experiência, e de debates que visem o (re)conhecimento de uma história que se encontra incorporada em nós mesmos.

A oralidade em África é mediadora das relações sociais, das relações políticas, econômicas e culturais. Tais características, como o respeito aos mais velhos, a coletividade, transmissão dos conhecimentos, elementos que reúnem em si valores educativos. É oportuno pensarmos em uma educação que contemple os elementos do universo cultural africano, já que estes adentraram nossa cultura. Muitas das práticas culturais desenvolvidas no Brasil, abarcam as práticas e costumes africanos, assim é importante que a escola também contemple os fatos históricos e culturais que envolvem o povo negro brasileiro.

Embora a instituição escolar não seja o único espaço para a construção de conhecimento sobre a cultura negra, ou sobre os legados de povos africanos, reconhecemos que é, no entanto, um espaço privilegiado para a superação de uma educação que ainda diminui a existência dos africanos e suas culturas.

Compreendemos que não há fórmulas educativas prontas, principalmente quando as práticas culturais e saberes africanos contidos na cultura dos negros no Brasil, ao serem pensados sob o ponto de vista da educação, são trabalhados no viés da educação não formal. Neste caso, observa-se entraves em sua inserção no currículo da educação formal, já que não são reconhecidos como "oficiais". Não é raro que a proposta de uma educação que contemple a tradição oral seja tomada como coisa pontual, no entanto, há possibilidades que nos auxiliam (des)cobrir caminhos para tais práticas e saberes, e "permitem de uma forma muito mais orgânica apreender as dinâmicas dos grupos e dos sujeitos em seus afazeres, valores, normas, comportamentos, etc" ${ }^{43}$.

Paula Junior ${ }^{44}$ nos traz como exemplo, o samba e a capoeira como expressões culturais que carregam, em seus símbolos e suas práticas, um vasto conjunto de informações que reúnem muito mais do que aquilo que é percebido num primeiro olhar, tais como as letras das músicas que trazem várias informações relevantes.

A mandiga na capoeira, ou seja, o disfarce expressa uma tática de desconstrução de uma ideia de poder que o opressor tende sempre a alimentar sobre o oprimido. Segundo Paula Junior ao citar Reis, a capoeira, esta luta-jogo não se propõe à agressividade, mas sim à defesa, e quando os lutadores se entendem o que temos é um diálogo corporal que se

\footnotetext{
${ }^{42}$ NUNES, Op. Cit.

${ }^{43}$ SILVA, Memória, tradição Oral e a afirmação da identidade étnica, p. 01.

${ }^{44}$ PAULA, Op. Cit.
} 
pauta no respeito ao outro, na condição do outro, algo que nos faz lembrar muito os valores propostos por Hampaté Bâ e que se tornam significativos para um entendimento maior da condição do homem no mundo ${ }^{45}$.

Segundo Paula Junior ${ }^{46}$ é o batuque de umbigada, dança de origem bantu praticada na região do médio Tietê, em cidades como Piracicaba, Capivari, Tietê e Rio Claro. Ao se dançar, o contato de umbigos entre o homem e a mulher, apresenta-nos o equilíbrio da criação e a continuidade da vida, um gesto que reflete toda uma perspectiva de observar o mundo. Essas práticas possibilitam uma vasta leitura da vida, escrita de um modo tal que apenas a oralidade consegue captar.

O hip hop, manifestação cultural, evoca referencial de respeito e o mesmo sentimento de unidade que se observa em culturas que remontam ao período escravista ${ }^{47}$.

O repertório cultural africano está ligado a cultura negra no Brasil e precisa se fazer presente na escola de forma efetiva. Entretanto para que esse caminho possa ser trilhado, é preciso pensarmos em uma pedagogia que permita aos alunos a valorização e respeito de nossos ancestrais e um diálogo constante que procure convergir os saberes comuns a cada povo e cultura para um encontro em que todos sejam valorizados.

Uma cantiga era sempre cantada nas aulas de Língua Portuguesa na Escola Primária 16 de Junho, é uma quadrinha antiga que as crianças cantam para assimilarem bem as tarefas que envolviam o uso das vogais. Segundo a professora regente da turma, ela ensinava essa cantiga, pois aprendera quando ainda era uma criança que estudava nas classes primárias. E assim essa pequena e singela quadrinha se repetia como uma forma de valorização do repertório cultural naquela comunidade escolar.

$$
\begin{aligned}
& \text { “O (a) é uma bolinha que tem uma perninha } \\
& \text { O (e) é uma bailarina que dá uma voltinha }
\end{aligned}
$$$$
\text { O (i) é uma igrejinha }
$$$$
\text { O (o) é uma bolinha }
$$

$$
\text { O (u) é o chifre da vaquinha” }{ }^{48} \text {. }
$$

Figura 3: Kelly Farias com as crianças na sala de aula da Escola Primária 16 de Junho.

\footnotetext{
${ }^{45}$ PAULA, Educação e oralidade no oeste africano pela representação de Amadou Hampâté Bâ, p. 128.

${ }^{46}$ PAULA, Educação e oralidade na cultura negra no Brasil, 2013.

${ }^{47}$ FÉLIX, Hip Hop: cultura e política no contexto paulistano, 2018.

${ }^{48}$ Notas do caderno de campo.
} 


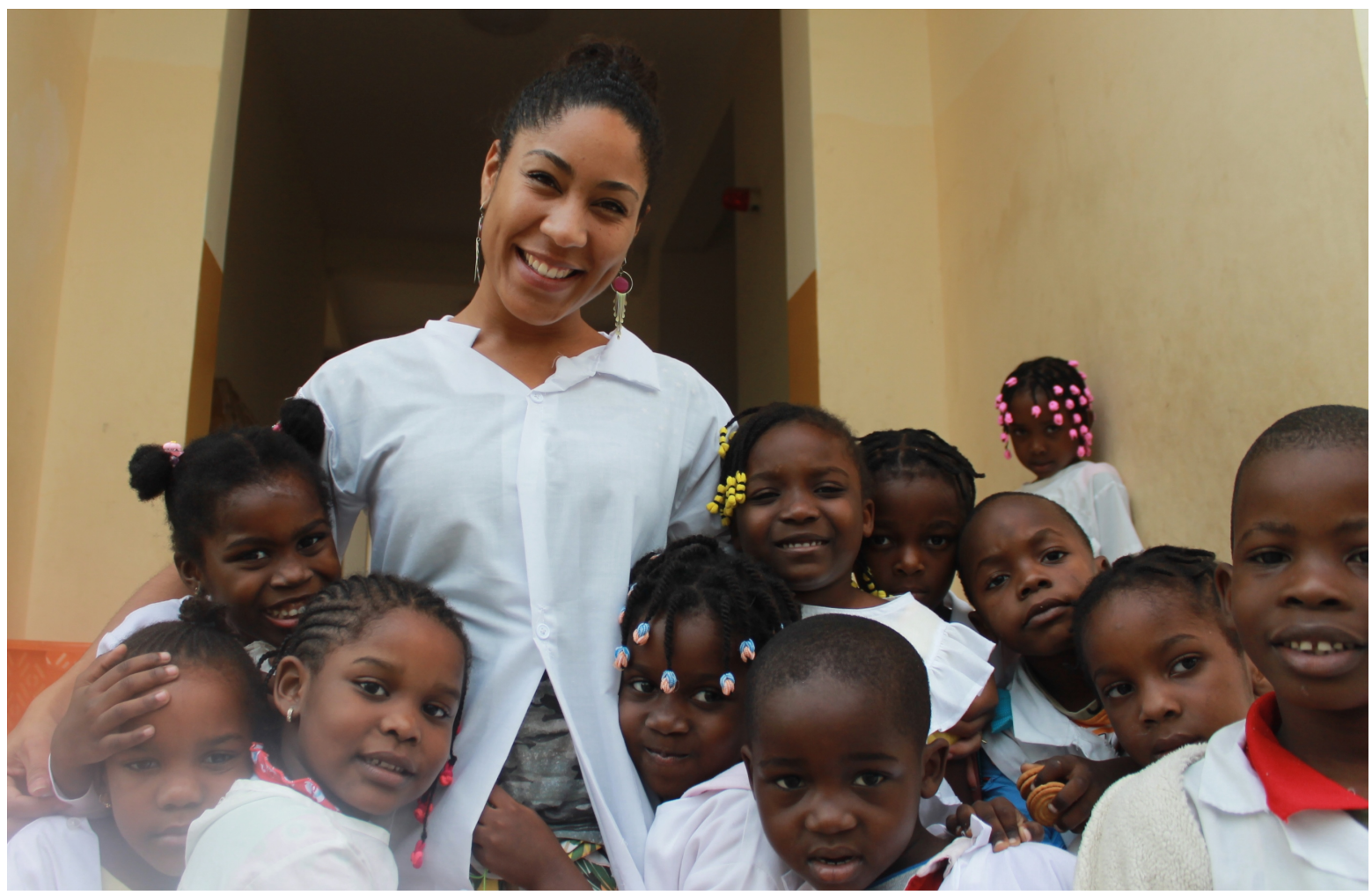

Fonte: arquivo pessoal de Kelly de Lima Farias.

Embora haja a constatação de que reunimos uma notável diversidade cultural, a escola brasileira muitas vezes cala essas vozes muitas vezes ignorando a senda de conhecimentos advindos das práticas culturais que têm a oralidade e a tradição como embasamentos. Cabe pensarmos em uma prática educativa que possibilite o povo brasileiro que se conheça nos muitos elementos de sua cultura, tal como o reconhecimento da sua própria construção histórica. Mais do que ministrar conteúdos sobre a África ou levar apresentar os valores da tradição oral africana, é importante percebê-la como agente formador da pessoa.

Kabengele Munanga, em "Superando o racismo na escola”, é bastante profícuo ao elucidar que o resgate da memória coletiva e da história da comunidade negra não interessa apenas aos alunos de ascendência negra, mas também aos alunos de outras ascendências étnicas, principalmente a branca.

Além disso, essa memória não pertence somente aos negros. Ela pertence a todos, tendo em vista que a cultura da qual nos alimentamos quotidianamente é fruto de todos os segmentos étnicos que, apesar das condições desiguais nas quais se desenvolvem, contribuíram cada um de seu modo na formação da riqueza econômica e social e da identidade nacional ${ }^{49}$.

${ }^{49}$ MUNANGA, Superando o racismo na escola, p. 16. 
Como já abordado ao longo desse trabalho, a palavra para as sociedades africanas, tem importância fundamental, é através dessa base sólida que se dá a transmissão da visão de mundo e saberes inerentes a um povo. A palavra cria, ressignifica o cotidiano, contribui com a troca de ideias, a contestação e a reflexão.

Nessa perspectiva, a educação que interage com o universo da tradição oral busca uma educação para a vida, para a totalidade das relações e interações humanas.

Hampâté $B \hat{a}^{50}$ aponta que os valores culturais africanos podem ser colocados à disposição do homem contemporâneo, pois muitos deles encerram valores universais, cabíveis à constituição do ser humano.

Na educação tradicional africana há uma interação entre os indivíduos e o seu meio, possibilita a harmonia do ser com ele mesmo e o mundo a sua volta, pois tudo está interligado. Podemos ponderar que trabalhar com os referenciais da cultura africana, auxilia na formação do ser humano para a vida, e não apenas para o atendimento de conteúdos.

Rosa Margarida de Carvalho Rocha traz uma consideração que nos ajuda a pensar uma educação na e pela tradição, para os africanos e afro-brasileiros:

A educação refere-se ao processo de 'construir a própria vida' que se desenvolve em relações entre gerações, gêneros, grupos raciais e sociais, com a intenção de transmitir visão de mundo, repassar conhecimentos, comunicar experiência. Na perspectiva africana, a construção da vida própria tem sentido no seio de uma comunidade, e visa não apenas o avançar de cada um individualmente. O crescimento das pessoas tem sentido quando representa fortalecimento para a comunidade a que pertence. ${ }^{51}$

Segundo Rocha ${ }^{52}$, a educação tem um vínculo comunitário e social, todos aprendem com todos, onde cada um tem sua parcela de contribuição.

Portanto, entendemos ser necessário dar visibilidade ao negro nos currículos escolares, tratando-o enquanto sujeito histórico.

Descobrir nossas raízes significa descobrirmos uma parte de nós que estava escondida, apagada pelo descaso e pelo desconhecimento da sociedade. Seja em nossa árvore genealógica, seja nos costumes, na religião, na culinária, na dança, no artesanato ou, enfim, na tradição deixada por nossos ancestrais e passada de pais para filhos, é a nossa história, o nosso

\footnotetext{
${ }^{50} \mathrm{BÃ}$, A tradição viva, 2010.

${ }^{51}$ ROCHA, A Pedagogia da Tradição: as dimensões do ensinar e do aprender no cotidiano das comunidades afrobrasileiras, p. 41.

52 Ibidem.
} 
patrimônio cultural que nos faz sentir orgulho do que somos e de quem somos, despertando-nos para a preservação de nossa herança cultural ${ }^{53}$.

Dessa forma, nos faz pertinente o pensamento de Glória Cecília de Souza e Silva ${ }^{54}$, quando apresenta a proposta de se buscar, na tradição oral, contribuições para se pensar o aqui e o agora, pois o presente da Educação está cheio de lacunas ancoradas nas mais variadas tradições científicas.

De acordo com Silva ${ }^{55}$ embora, não seja objetivo da ciência, encontrar respostas definidas para qualquer problema, incluir outras tradições no debate, principalmente quando há a preocupação de se repensar processos e práticas educativas que contribuam para humanizar homens e mulheres, tem sim, o seu valor.

À vista disso, a oralidade, sendo elemento da tradição africana que traz consigo resistência, conhecimento e preservação dos referenciais culturais, ao dialogar com a educação tem muito a contribuir, seja na própria reconstrução histórica de um povo, seja na construção de um conhecimento no qual o ser se envolve na totalidade.

\section{Considerações finais}

A história oral tem sido um campo de investigação de relevância para a história dos povos africanos. Ao falarmos em África, certamente falaremos da oralidade, traço marcante dessa cultura. A oralidade aqui não é pensada como uma fala informal, mas uma fala que há vida, memória e resistências.

A oralidade presente na tradição oral nos apresenta a configuração social de sua sociedade, permite que reconheçamos através dos traços dessa cultura tanto os caminhos percorridos, como também perceber os desafios para que haja a consolidação de seus costumes, ritos etc.

Algumas designações para a tradição oral, têm sido utilizadas por autores como Susana Dolores Machado Nunes. Segundo ela, quando essa cultura é expressa em letras, é designada como oratura, pois leva de algum modo toda a carga simbólica e valorativa da tradição oral ao corpo do texto.

A África tem sido despertada para sua história, uma história contada por sua própria voz, tendo na tradição oral os principais elementos que caracterizam um modo de ser africano que propicia uma representação mais próxima de sua identidade.

Através do trabalho com a tradição oral reconhecemos o conjunto de valores sociais, religiosos, educacionais veiculados pela oralidade, que, por conseguinte, nos permite

\footnotetext{
${ }^{53}$ GOMES apud NUNES, A cultura de base africana e sua relação com a educação escolar, p. 41.

${ }^{54}$ SILVA, Os "Fios de Contos” de Mãe Beata de Yemonjá: mitologia afro-brasileira e educação, 2008.

${ }^{55}$ Ibidem.
} 
entender como as sociedades recordam e constroem suas memórias, bem como imprimem sua identidade.

De acordo com Vansina ${ }^{56}$, "a oralidade é uma atitude diante da realidade e não a ausência de uma habilidade”. A oralidade determina um modo de ser, de pensar, de agir, ou seja, todo um modo de educar e aprender estão configurados no universo tradicional.

Nesse sentido que buscamos nesse trabalho, refletir sobre a importância da tradição oral africana e a riqueza de conhecimentos que emanam dessas narrativas. Pois "quanto mais a tradição consegue dialogar com o mundo a sua volta, mais ela é fortalecida" ${ }^{57}$. E, a partir delas, repensar as possibilidades de trabalhá-las na Educação brasileira. Pois a tradição oral não se trata apenas de conhecimentos a serem transmitidos, ou ritos e lendas, mas de formas de se olhar para si e para o outro que fortaleçam a dignidade, o respeito e principalmente um sentido de vida.

\section{Referências}

BÂ, Amadou Hampâté. A tradição viva. In: ZERBO, Joseph Ki (org). História Geral da África I: Metodologia e pré-história da África. Brasília: UNESCO, 2010.

BÂ, Amadou Hampâté. Confrontações culturais: entrevista concedida a Philippe Decraene. THOT, no 80, abr 2004, p. 03-12.

FÉLIX, João Batista de Jesus. Hip Hop: cultura e política no contexto paulistano. Curitiba: Apris, 2018.

LEITE, Ana Mafalda. Oralidades e Escritas nas Literaturas Africanas. Lisboa: Edições Colibri, 2014.

MUNANGA, Kabengele (org.). Superando o racismo na escola. Brasília: Ministério da Educação/Secretaria de Educação Continuada/Alfabetização e Diversidade, 2005.

NUNES, Cícera. A cultura de base africana e sua relação com a educação escolar. Revista Metáfora Educacional, no 10, jun. 2011. p. 38-50. Disponível em: <http://www.valdeci.bio.br/revista.html>. Acesso em: 01 dez. 2016.

NUNES, Susana Dolores Machado. A milenar arte da oratura angolana e moçambicana: aspectos estruturais e receptividade dos alunos portugueses ao conto africano. Porto: Centro de Estudos Africanos da Universidade do Porto, 2009. E-book; CEAUP Edições eletrônicas. Disponível em: <http://www.africanos.eu/ceaup/uploads/EB015.pdf>. Acesso em 01 set. 2016.

\footnotetext{
${ }^{56}$ VANSINA, A tradição oral e sua metodologia, p. 140.

${ }^{57}$ PAULA, Educação e oralidade no oeste africano pela representação de Amadou Hampâté Bâ, p. 107.
} 
OLIVEIRA, Julvan Moreira de. Africanidades e educação: ancestralidade, identidade e oralidade no pensamento de Kabengele Munanga. Tese de Doutorado - Faculdade de Educação, Universidade de São Paulo, São Paulo, 2009. Disponível em: $<$ www.teses.usp.br/teses/disponiveis/48/48134/tde-20042010-153811>. Acesso em: 20 de novembro de 2016.

OLIVEIRA, Julvan Moreira de; NASCIMENTO, Sérgio Luis do. A Construção do Legado: a negação de uma epistemologia filosófica africana. Revista $A B P N$, vol. 8, n 19 . Mar-Jun 2016, p. 177-194. Disponível em: $<$ http://www.abpnrevista.org.br/revista/index.php/revistaabpn1/article/view/31>. Acesso em: 11 de agosto de 2018.

PAUlA Jr, Antônio Filogênio de. Educação e Oralidade na Cultura Negra no Brasil. Piracicaba: UNIMEP, 2013.

PAULA Jr, Antônio Filogênio de. Educação e oralidade no oeste africano pela representação de Amadou Hampâté Bâ. 2014. 158 p. Dissertação (Mestrado em Educação) - Faculdade de Ciências Humanas, Universidade Metodista de Piracicaba: SP, 2014.

RIBAS, Oscar. Temas da vida angolana e suas incidências. Luanda: Edições Chá de Caxinde, 2002.

ROCHA, Rosa Margarida de Carvalho. A Pedagogia da Tradição: as dimensões do ensinar e do aprender no cotidiano das comunidades afro-brasileiras. Revista Paidéia, ano 8, n 11, jul-dez 2011, p. 31-52.

SILVA, Acildo Leite da. Memória, tradição Oral e a afirmação da identidade étnica. GT: Afro-brasileiros e educação. 27 ${ }^{a}$ Reunião da ANPED, 2006. Disponível em: $<$ http://27reuniao.anped.org.br/gt21/t211.pdf $>$. Acesso em: 11 de agosto de 2016.

SILVA, Gloria Cecília de Souza e. Os "Fios de Contos" de Mãe Beata de Yemonjá: mitologia afro-brasileira e educação. 2008. 137 p. Dissertação (Mestrado em Educação) - Faculdade de Educação, Universidade do Estado do Rio de Janeiro, Rio de Janeiro, 2008. Disponível em: <http://www.proped.pro.br/teses/teses_pdf/2006 1-190-ME.pdf>. Acesso em: 01 de dezembro de 2016.

VANSINA, Jan. A tradição oral e sua metodologia. In: ZERBO, Joseph K. (org). História Geral da África I: Metodologia e pré-história da África. Brasília: UNESCO, 2010. 